\title{
TARTARUGAS NA AMAZÔNIA: NOTAS INTERPRETATIVAS SOBRE PRESERVAÇÃO ENTRE OS QUILOMBOLAS DO ALTO TROMBETAS, ORIXIMINÁ, PARÁ
}

\author{
Juliana Cardoso Fidelis (D) $\triangle$
}

Pós-Graduação em Ciências Sociais I Campinas - SP - Brasil

Evillys Martins de Figueiredo (1) $\triangle$ 
Este artigo objetiva esboçar notas interpretativas sobre a concepção quilombola de preservação ambiental e como essa concepção se relaciona às ações de conservação operadas pelo ICMBio na região do Alto Trombetas (Oriximiná, Pará). Refletimos via narrativa do encantado João Diriguidon, articulando a figura do narrador, memória coletiva, reciprocidade e conhecimento local relativo às transformações advindas da sobreposição de duas Unidades de Conservação aos territórios quilombolas. A narrativa apresenta elementos da relação entre humanos, tartarugas e encantados no rio Trombetas; informa sobre acordos sociais e ecológicas quilombolas, e possibilita compreender a preservação em relação às ações de conservação do ICMBio. Nesse cenário de disputas e aproximações quanto ao futuro dos "bichos de casco", em especial de Podocnemis expansa na Amazônia, concluímos que, apesar dos conflitos ligados às restrições de uso de recursos ambientais nas unidades, preservação e conservação não são conceitos incomensuráveis, mas partes diferentes de um processo que objetiva a salvaguarda das tartarugas.

Palavras-chave: quilombolas; narrativa; tartaruga; preservação; unidades de conservação

\section{TURTLES IN THE AMAZON: INTERPRETATIVE NOTES ON PRESERVATION AMONG THE QUILOMBOLAS OF ALTO TROMBETAS, ORIXIMINÁ, PARÁ}

\section{ABSTRACT}

This paper aims to outline interpretative notes on the quilombola concept of environmental preservation and how this concept relates to the conservation actions operated by ICMBio in the Alto Trombetas region (Oriximiná, Pará). We reflect via the narrative of the enchanted João Diriguidon, articulating the narrator figure, collective memory, reciprocity and local knowledge, regarding the transformations arising from the overlapping of two Conservation Units to the quilombola territories. The narrative presents elements of the relationship among human, turtles and enchanted beings in the Trombetas river; it informs about quilombolas social and ecological agreements, and it enables the comprehension of preservation related to ICMBio's conservation actions. In this scenario of disputes and approximations regarding the future of "hoofed animals", especially of the Podocnemis expansa in the Amazon, we conclude that, despite the conflicts related to the restrictions on the use of environmental resources in the units, preservation and conservation are not immeasurable concepts, but different parts of a process that aims to safeguard turtles.

Keywords: quilombolas; narrative; turtle;

preservation; conservation units.

\section{TORTUGAS EN LA AMAZONÍA: NOTAS INTERPRETATIVAS SOBRE PRESERVACIÓN ENTRE LOS QUILOMBOLAS DEL ALTO TROMBETAS (ORIXIMINÁ, PARÁ, BRASIL) RESUMEN}

El presente artículo tiene como objetivo esbozar notas interpretativas sobre la concepción quilombola de preservación ambiental y cómo ella se relaciona con las acciones de conservación aplicadas por ICMBio en la región de Alto Trombetas (Oriximiná, Pará, Brasil). Reflexionamos a través de la narrativa del encantado João Diriguidon, articulando la figura del narrador, la memoria colectiva, la reciprocidad y el conocimiento local relacionados con las transformaciones resultantes de la superposición de dos Unidades de Conservación en territorios quilombolas. La narrativa presenta elementos de la relación entre humanos, tortugas y encantados en el rio Trombetas; advierte sobre las relaciones sociales y ecológicas quilombolas; y permite comprender la preservación en relación con las acciones de conservación de ICMBio. En este escenario de disputas y acuerdos sobre el futuro de los “animales con caparazón”, particularmente de la Podocnemis expansa en la Amazonía, concluimos que, a pesar del conflicto relacionado con las restricciones sobre el uso de los recursos ambientales en las UCs, la preservación y la conservación no son conceptos inconmensurables, sino diferentes partes de un proceso que tiene como objetivo la salvaguardia de la tortuga.

Palabras clave: quilombolas; narrativa; tortuga; 


\section{INTRODUÇÃO}

$\mathrm{Na}$ literatura antropológica clássica e contemporânea, encontramos trabalhos que tratam das relações entre humanos e não humanos, as quais são capazes de apresentar um sem número de arranjos socioculturais, significações e efeitos práticos na vida social (O’Dwyer 2008; Teixeira 2011; Wawzyniak 2003, 2008, 2012). Essas dimensões podem servir de modelos interpretativos e orientam a observar a diversidade humana no sentido de que as interações entre humanos e não humanos são importantes por constituírem um dos aspectos das relações de produção de significados e de (re)produção da vida material das sociedades.

Evans-Pritchard (1978) interpretou o universo organizacional dos Nuer enquanto grupo em si mesmo e em sua interação com demais grupos vizinhos em função de uma gramática social atravessada pela sua cumplicidade para com o gado. Já na disputa em torno das brigas de galos balinesas, estudadas por Geertz (2008), o galo e o jogo tornam-se símbolos culturais interrelacionados, capazes de expressar, entre muitos aspectos, uma dinâmica de poder centrada na figura masculina, que, ao ser metaforizada no incentivo que os homens dirigem aos seus "bichos" para lutarem violentamente durante a briga, informam como a figura masculina e a atuação do galo se retroprojetavam nesses jogos.
Inspirando-nos no exercício da comparação em Antropologia, neste artigo trataremos da narrativa sobre "João Diriguidon", um homem que, de acordo com uma cosmologia presente do rio Trombetas, se encantou junto a uma tartaruga por não ter respeitado os acordos sociais locais sobre a pesca desse animal. Assim, objetivamos esboçar notas interpretativas sobre a concepção quilombola de preservação ambiental e de como ela se relaciona às ações de conservação operadas pelo Instituto Chico Mendes de Conservação da Biodiversidade (ICMBio), na região do alto Trombetas, no município de Oriximiná, estado do Pará.

Uma narrativa conta mais do que uma simples história. Ela apresenta um contexto onde o próprio narrador se projeta enquanto parte de um grupo social (Maluf 1999). Partindo da narrativa, problematizaremos em que medida ela expressa certa "incomensurabilidade" (Almeida 2003) entre "preservar" e "conservar" no contexto socioambiental do Trombetas.

A narrativa aqui estudada informa e ensina para as novas gerações uma concepção de preservação situada, ou seja, que integra os acordos ecológicos existentes entre humanos $\mathrm{e}$ não humanos na região, especificamente com as tartarugas. A concepção ou a ideia de preservação quilombola expressa é acionada pelos narradores 
por meio da memória coletiva e do contexto mais "abrangente" do Trombetas, cercado de agentes e políticas transformadoras, que influenciam a vida dos quilombolas da região desde a década de 1970.

Em linhas gerais, a concepção local de preservação pode ser entendida sob uma dupla dimensão: articulação da memória coletiva (Halbwachs 2003) a uma "orientação da atenção" (Ingold 2010), realizada entre gerações e relacionada à dimensão sociopolítica pelo contraste e pela interação com categorias externas, como a de conservação. A preservação expressa aspectos da dinâmica local de classificação, que atualiza tradição, memória, conceitos nativos e comportamentos sociopolíticos frente à presença e à atuação de um órgão federal.

Para compreender os sentidos quilombolas de "preservação" figurada na narrativa, é necessário considerá-la em relação ao que os comunitários comentam a respeito da concepção institucional de conservação, vinculada à gestão dos recursos ambientais realizada por técnicos do ICMBio no Trombetas. Apesar de o foco de compreensão ser a narrativa quilombola, em alguma medida, perpassaremos pela ideia institucional de conservação, pois ela é um dos fatores que incide sobre a dinâmica social local com relação aos animais.

Neste artigo, propomos este "experimento imaginativo" partindo do contato com tais populações em campo, possibilitado por leituras e experiências compartilhadas entre pesquisador e interlocutores em campo (Viveiros de Castro 2002). Tais experimentos configuram uma "ficção antropológica", que "toma" as ideias dos interlocutores como conceitos ${ }^{1}$, pois é sobre os entendimentos nativos sobre as coisas que se pretende falar (Viveiros de Castro 2002). Trataremos as concepções/classificações quilombolas que compõem a narrativa como produtos suscetíveis a mudanças social em decorrência de "políticas" ambientais exógenas, de modo a inserir nossa interpretação textual ${ }^{2}$ no "jogo social de construção de sentido" (Rocha \& Eckert 2004:7) que envolve a narrativa.

Assim, o presente trabalho parte das concepções quilombolas no Trombetas quanto à diferença entre preservação e conservação, as quais representam mundos e perspectivas possíveis, e potencialmente dialógicos (Almeida 2003), expressos no ato de narrar que aciona os

1 Nesse caso, o autor toma os conceitos relacionados às ideias e aos problemas da razão indígena. Entretanto, no presente artigo, entendemos que esse princípio pode ser utilizado para considerar os conceitos quilombolas, por conta das profundas relações entre essas comunidades, como veremos adiante.

2 Construímos esse texto etnográfico sabendo das tensões que envolvem a tríade tradução/tradutor/traidor no processo de "tradução" da fala "nativa", na linguagem escrita, pois a intenção de interpretar uma narrativa como essa se defronta com constrangimentos linguísticos do código escrito que potencialmente alteram o seu status (Rocha \& Eckert 2004:7). 
conhecimentos locais. Os narradores ensinam às novas gerações quilombolas, por meio da oralidade, sobre saberes, acordos, tabus e sanções sociais referentes ao ciclo de reciprocidade que rege a interação entre humanos e não humanos para a manutenção do meio ambiente e do modo de vida quilombola, aspectos que relacionam a organização social local - quanto às dinâmicas de preservação próprias - com as ações de conservação do ICMBio.

\section{O RIO TROMBETAS E SEU ENTORNO}

Nesta primeira parte, caracterizamos o cenário do Trombetas. A ocupação negra nesse lugar remonta aos séculos XVIII e XIX, com a formação dos primeiros "mocambos" no alto curso encachoeirado do rio e de seus afluentes, como Erepecuru, Acapu e Cuminá (Acevedo \& Castro 1998). Os mocambeiros, como eram denominados os negros escravizados que fugiam dos domínios senhoriais, construíram sua autonomia por meio da construção progressiva do conhecimento do território, do estabelecimento de trocas mercantis com comerciantes locais e das relações de aliança e/ou conflito com outros grupos étnicos da região - como os indígenas -, importantes fatores à construção de marcas identitárias específicas e à sua reprodução material, simbólica e cultural (Acevedo \& Castro 1998).
Salles (2005:237) demonstra que, por vezes, o negro estava sozinho, mas conseguia chegar a alguma aldeia indígena e, com sorte, acabava vivendo nela amistosamente. Henri Coudreau (1886, 1903 apud Fidelis 2019) destaca um intercâmbio de mercadorias e uma ampla relação dos povos de língua Karib com seringueiros, castanheiros e quilombolas da região. Barbosa Rodrigues (1875 apud Fidelis 2019) assinala que os mocambistas se integraram a uma grande rede de negociações com indígenas, "donos da terra" etc. Howard (2002) demonstrou que os Wabui ${ }^{3}$, antepassados dos Waiwai, estabeleciam trocas comerciais com os negros na região por conta das “caçadas" aos escravizados fugidos, organizadas por missionários que obrigavam os Wabui a "descer" o rio Trombetas (Howard 2002:31). Embora nem sempre pacíficas, essas interações renderam casamentos interétnicos, mobilidade local e circulação de produtos extrativistas e mercadorias externas.

Na segunda metade do século XIX, com as fugas, a constituição dos saberes quilombolas foi decisiva para que eles obtivessem o que não podiam produzir. O comércio extrativista, de certo modo, integrou essa população à economia regional e a importância econômica dos quilombos amazônicos atingiu seu

3 A pronúncia da palavra lembra "Abuí", termo que dá nome ao lago e a uma das últimas comunidades quilombolas na ascensão do Trombetas. 
auge, pois houve um período de alta dos preços de produtos florestais nos mercados internacionais; consequentemente, foi o fim das medidas repressivas e punitivas a essas populações (Scaramuzzi 2016). Os quilombolas também comercializavam produtos com os "regatões", atravessadores de mercadorias dos núcleos urbanos de Oriximiná e Óbidos, e detiveram o monopólio da atividade extrativa local. Essa inserção às chamadas "cadeias produtivas" local e internacional ocorreu devido aos seus conhecimentos práticos e diferenciados sobre variadas espécies de plantas e animais, seus comportamentos e qualidades ${ }^{4}$. Portanto, atividades de coleta, extrativismo e caça, importantes fontes de subsistência, ajudaram a caracterizar ribeirinhos e quilombolas como comunidades extrativistas e/ ou "tradicionais" na região amazônica.

Nas décadas seguintes à abolição da escravatura, em 1888, os mocambos se transferiram gradativamente para o curso mais baixo dos rios, em zonas de navegação mais próximas aos núcleos urbanos, para formar povoados que depois foram reconhecidos como "comunidades remanescentes de quilombo" pela Constituição Federal de 1988 (CF/88). Durante a nova constituinte, o tema dos "remanescentes" passou a ter visibilidade e, com isso, as comunidades passaram progressivamente a reivindicar ${ }^{5}$ a titulação dos atuais territórios quilombolas, com base no artigo 68 do Ato das Disposições Constitucionais Transitórias (ADCT) da $\mathrm{CF} / 88$. Assim, os territórios Boa Vista, Água Fria, Trombetas e Erepecuru foram titulados em 1995, 1996, 1997 e 1998, respectivamente; Cachoeira Porteira, em 2018; Ariramba, parcialmente titulado em 2018; já o Alto Trombetas I foi parcialmente titulado na década de 1990 e, atualmente, aguarda titulação de outra porção territorial, juntamente com o Alto Trombetas II, que ainda não possui área titulada ${ }^{6}$ (Fidelis 2019:28).

Em 2007, o ICMBio foi criado e tornou-se responsável pela gestão de duas Unidades de Conservação (UC) $)^{7}$ federais que foram instaladas sobre áreas já ocupadas predominantemente por comunidades negras rurais (Acevedo \& Castro 1998; Salles 2005; Scaramuzzi 2016; Wanderley 2005). Tendo isso em vista, a disputa entre as então comunidades quilombolas e o órgão federal ambiental em torno do que os quilombolas chamam 4 Sobre isso, ver Carvalho (2013) e Santos \& Carvalho (2015).

5 Com apoio da Igreja Católica, que, até hoje, é objeto de nítidas lembranças entre os quilombolas. Frequentemente, eles narram o trabalho e as ações das Comunidades Eclesiais de Base (CEB) que ajudaram a conferir a essas populações instrumentos importantes para o seu progressivo autorreconhecimento (Fidelis 2019:28).

6 Para melhor detalhamento sobre esses processos, ver Fidelis (2019).

7 Função que, inicialmente, foi do Instituto Brasileiro de Desenvolvimento Florestal (IBDF), órgão federal criado em decorrência do estabelecimento do Código Florestal de 1965 e que atuou no Trombetas na década de 1960, até ser substituído pelo Instituto Brasileiro do Meio Ambiente e dos Recursos Naturais Renováveis (lbama), em 1989. Esse órgão transferiu a gestão das UC para o ICMBio. 
de "pesca/captura" dos "bichos de casco" no rio Trombetas é de onde parte nossa interpretação.

Durante muito tempo, as práticas e os modos de viver dessas comunidades tradicionais foram vistos como "entraves ao desenvolvimento" (Cunha 2009). Esse discurso foi considerado nas discussões sobre as ações de conservação ambiental, que culminaram na criação de áreas protegidas na América Latina (Zhouri et al. 2007). Vistas como caminhos para o chamado "desenvolvimento sustentável”, essas ações se configuram sob a égide da gestão de conflitos (Zhouri 2008), onde surgem e se situam as políticas de conservação de diversos órgãos ambientais no Brasil (como o ICMBio). Os quilombolas do Trombetas experenciam tais políticas e ações, as contrastam com as concepções locais e, desde 1980, essas interações orientam um campo consensual prático "inerente à noção de desenvolvimento sustentável [...] que aposta na possível conciliação entre os 'interesses' econômicos, ecológicos e sociais, abstraindo dessas dimensões as relações de poder que, de fato, permeiam a dinâmica dos processos sociais" entre os ocupantes do território (Zhouri 2008:97).

Baseando-snos nos saberes quilombolas construídos nas suas relações com as populações circundantes, a floresta e os animais que povoam o território (Scaramuzzi 2016), situamos nossa reflexão no âmbito dos estudos das relações ecológicas e ambientais dessas comunidades, uma vez que referências como a de Scaramuzzi (2016) possibilitaram abrir caminhos interpretativos a respeito das noções e ações de salvaguarda da fauna e da flora locais.

A tartaruga-da-amazônia (Podocnemis expansa) é uma espécie presente no rio Amazonas e seus afluentes ${ }^{8}$. No Brasil, ela se distribui pelas regiões Norte e Centro-Oeste e encontra-se no leito de rios e lagos (Francisco 1997), predominantemente no rio Trombetas9. Segundo o Plano de Manejo da Reserva Biológica (REBIO) (Brasil 2004), a tartaruga-da-amazônia adulta constitui-se em quelônio por conta de suas características físicas ${ }^{10}$. O período de "nidificação" ${ }^{11}$ no Trombetas acontece no mês de outubro.

8 Seu habitat incide por quase sete milhões de $\mathrm{km}^{2}$, compreendendo a Amazônia peruana, boliviana, colombiana, venezuelana e, sobretudo, brasileira (Corrêa 1978). No Brasil, a área de incidência da espécie por colônias se estende por uma vasta porção do território da Calha Norte. Segundo dados do Instituto do Homem e Meio Ambiente da Amazônia (Imazon 2013), essa área corresponde a uma zona de 270 mil quilômetros, o equivalente a $22 \%$ do estado do Pará, dividida em nove municípios.

9 Onde outras espécies podem ser encontradas livremente nos diversos cursos de água da região. É o caso de espécies como o tracajá (Podocnemis unifilis), o pitiú (Podocnemis sextuberculata) e o cabeçudo (Peltocephalus dumerilianus) (Ernst \& Barbour 1989).

10 Carapaça achatada e mais larga na região posterior, de coloração marrom, cinza ou verde-oliva.

11 Quando a fêmea desova, geralmente, mais de 130 ovos por postura. 
A Calha Norte situa-se na margem esquerda da mesorregião do baixo Amazonas e é conhecida como um "mosaico"12, sendo composta por áreas protegidas que abrigam as maiores UC dos trópicos. Já Oriximiná é um dos maiores municípios do mundo $\left(107.603,292 \mathrm{~km}^{2}\right)$ e abriga três grandes UC: a Floresta Estadual do Rio Trombetas, a Reserva Biológica do Rio Trombetas e a Floresta Nacional (FLONA) de Saracá-Taquera. Além da biodiversidade, uma das características mais marcantes do município é a diversidade étnica, vide a presença de muitas áreas indígenas e oito territórios quilombolas (IBGE 2010 apud Fidelis 2019).

Atualmente, há diferentes políticas de conservação associadas às duas UC implantadas na região. A mais severa delas chegou com a instalação da REBIO do Rio Trombetas, em 1979, uma UC de Proteção Integral que, a rigor, proíbe a presença dos moradores locais. Inaugurou-se, então, um tempo em que as atividades de subsistência ou a prática do banho de rio dos comunitários no território passaram a ser consideradas "fora da lei", podendo lhes gerar prejuízos, por não responderem "adequadamente" às restrições estabelecidas nas UC, como multas e, por vezes, o confisco de bens de locomoção e ferramentas de trabalho ${ }^{13}$.

Os quilombolas relataram que um dos efeitos de conviver com as políticas ambientais do órgão e com o maior projeto de extração de minério da Calha Norte, é essa sobreposição ${ }^{14}$ das UC aos territórios antes ocupados e utilizados por seus ancestrais. Isso se tornou motivo para a mobilização desses agentes em direção à titulação de seu território e intensificou a luta por outros direitos (Arruti 2006, 2013; Fidelis 2019). Assim está disposto o conflito entre quilombolas e as políticas do ICMBio, pois essa relação é atravessada pelas mudanças significativas operadas pelo órgão no trato com os moradores da área, devido às regras e aos projetos das UC. No caso do Trombetas, a REBIO está sobreposta em parte considerável do território pleiteado pelos quilombolas; abaixo da REBIO, está a FLONA de Saracá-Taquera, a UC de Uso Sustentável onde, apesar das demasiadas restrições aos quilombolas quanto à extração de recursos florestais, a empresa Mineração Rio do Norte (MRN) tem autorização pelo ICMBio para explorar bauxita.

No âmbito das UC na década de 1970, o IBDF administrou o Serviço de Proteção à Tartaruga do

12 Criada pela lei n. 9.985/2000 e pelo decreto federal n. 4.340/2002, com a institucionalização e a regulamentação em formato de mosaico (Ideflor-bio 2016).

$13 \mathrm{O}$ contexto é também marcado por anteriores abusos de poder praticados pelo corpo técnico do antigo IBDF, os quais, sem dúvidas, deixaram marcas ainda hoje sentidas e temidas pelos moradores.

14 Para um melhor detalhamento do conflito, ver Fidelis (2019) e Wanderley (2008). 
rio Trombetas, ao substituir a Superintendência do Desenvolvimento da Pesca (Sudepe), passando a controlar alguns dos tabuleiros de desova; assim, o governo federal determinou que fossem realizados os primeiros "levantamentos e aspectos organizacionais" do projeto de proteção e manejo intitulado "Projeto Quelônios da Amazônia", que incluía "os tabuleiros de desova das tartarugas, da recém-criada Reserva Biológica [...] juntamente com outras áreas de relevância, ao longo da bacia amazônica” (Brasil 2004:121).

No "Projeto Quelônios", a UC foi enquadrada como área prioritária para estudos e pesquisas permanentes sobre as espécies de tartarugas, principalmente a Podocnemis expansa. A metodologia para o projeto foi organizada e sugerida por Cantarelli (1980 apud Brasil 2004:121122). Os procedimentos são: 1) seleção de áreas de desova; 2) limpeza da área de desova; 3) vigilância e proteção da área de desova; 4) localização e identificação das desovas; 5) transferências das desovas; 6) controle da eclosão dos ovos; e 7) manejo dos filhotes. Atentemos para três etapas: a 5 refere-se ao "controle" de área com a interferência técnica humana na troca do lugar da desova; a 6 , ao monitoramento dos ninhos para evitar predação humana; e a 7, ao momento da coleta dos filhotes que saem espontaneamente da cova para retirada dos demais. Na etapa 7, os filhotes são transferidos a um berçário construído nas partes baixas da praia ou aos tanques de alvenaria na sede da REBIO. Os recém-nascidos lá permanecem por até quinze dias para, então, adquirirem a liberdade nos lagos da reserva. Por isso, é feita a proibição da presença de humanos (Brasil 2004). Adequada à metodologia de conservação da espécie no projeto, a categoria "quelônio" foi introduzida no meio comunitário e nos projetos oficiais em parceria com a própria MRN, os quais contam com a presença e "colaboração" das comunidades (Fidelis 2019).

Desde o trabalho de campo, a tensão entre os usos dos recursos ambientais por parte dos quilombolas e as restrições advindas das políticas ambientais do ICMBio foram sobressaltadas. Quando questionados sobre a política de preservação desempenhada pelos técnicos do ICMBio no entorno da REBIO, os quilombolas não explicaram de maneira aberta e direta a atuação do órgão, mas relataram algumas histórias relacionadas às suas práticas e às "punições" que já sofreram e que ainda sofrem. Assim, não houve explanação dada sobre qualquer conduta ambiental do órgão, apenas impressões repassadas em conversas descontraídas de que os técnicos se abriram à interpretação a partir do convívio com os moradores da região.

Sobre e no entorno dessas comunidades, 
portanto, encontram-se a MRN, sua company tow $n^{15}$ Porto Trombetas, o ICMBio e as UC. Quilombolas, técnicos e empregados da empresa convivem há mais de 40 anos, compondo um complexo universo territorial em disputa, sob transformações que ainda influenciam a dinâmica social quilombola. Mesmo transformado, o território descrito pelos quilombolas ainda é constituído por lugares de encantes, onde vivem as "mães" de rios e matas (Teixeira 2011), e pelo espaço da vida doméstica, onde moram e cultivam roças, ao mesmo tempo em que há o "espaço da empresa” (Fidelis 2019); ou seja, estabeleceram uma estreita relação com o território e com os humanos e não humanos que interagem a partir de diferentes lugares físicos e simbólicos.

Com a histórica interação supracitada desses povos com a biodiversidade local, os costumes desenvolvidos também se nutrem em passado ancestral, compartilhados pelas comunidades do Trombetas, Erepecuru e Cuminá, que está presente nas narrativas locais, o que O'Dwyer (2002:264) chamou de "gosto pelas origens", uma forma, pela via da experiência, de forjar uma procedência comum aos negros ocupantes desses rios, criando uma "história dos princípios" composta de narrativas relacionadas às fugas empreendidas pelos negros escravizados, mas também se refere a um tempo onde a caça de tartarugas era controlada não por órgãos federais, mas em função do receio sobre a "encantaria" que leva ao fundo do rio (Fidelis 2019:32).

\section{UNIDADES DE CONSERVAÇÃO, NARRATIVAS E CONCEPÇÕES EM DISPUTA}

Nossa discussão parte de dados etnográficos colhidos nas conversas, entrevistas e observações, realizadas pela primeira autora em três viagens de campo ao alto Trombetas, no final de 2016, em dois períodos de 2017 e em um período de 2018. Em 2016, a pesquisadora entrou na região atuando como técnica no licenciamento ambiental ${ }^{16} \mathrm{de}$ uma nova zona de exploração de bauxita da empresa MRN. Concluído o estudo, entre 2017 e 2018, passou a investigar questões referentes à sua pesquisa de mestrado (Fidelis 2019).

Com a mudança na posição quilombola no jogo socioambiental ocorrida, sobretudo, com a mobilização pela titulação efetiva de suas terras inclusive de onde se projetam as UC -, atualmente, é possível compreender a existência de um "debate", mais do que um "embate", entre distintas concepções, pois os quilombolas elaboraram uma espécie de "simbolização ou prática de sentido",

15 As "cidades operárias" criadas para abrigar toda a estrutura e os funcionários de empresas.

16 Tratou-se de relatórios para o Estudo do Componente Quilombola (ECQ), peça técnica obrigatória no Estudo de Impactos Ambientais (EIA), realizados nos territórios Boa Vista, Alto Trombetas I e Alto Trombetas II. 
que os permite criar dispositivos autorreferenciais em meio a esse jogo e que produzam seus próprios conceitos (Viveiros de Castro 2002:131).

É nesse espaço de "fricção" que se configura e se projeta esse debate, em pleno cotidiano local, pois os agentes envolvidos demarcam continuamente suas ações com relação ao meio ambiente. Apesar de serem assimétricas, as concepções em jogo acabam, de certa forma, se complementando com relação à finalidade do equilíbrio ecológico e, assim, podemos considerá-las partes integrantes de um processo de cismogênese (Bateson 2008), ou seja, processos de diferenciações, que pressupõem divisões dentro dos grupos sociais em disputa, com relação à classificação das coisas e dos seres, destacando criações e separações. Por meio desse processo, podemos entender a ideia de integridade e ruptura que envolve as ideias de preservação e conservação, pois elas podem ser compreendidas como aspectos diferentes, mas não opostos, porque são faces de processos de produção de sentidos.

Nesse panorama, alimenta-se e projeta-se a concepção local de preservação, dinamizada pelas transformações sociais e pela memória coletiva. A memória coletiva é "o processo social de reconstrução do passado vivido e experimentado por um determinado grupo [...]. Este passado vivido é distinto da história, a qual se refere mais a fatos e eventos registrados [...], independentemente destes terem sido sentidos e experimentados" (Halbwachs 2003:224).

O cenário exposto confere base para se trabalhar com narrativas. Segundo Turner (1992 apud Arruti 1996), elas são fontes morais para o desempenho dos atores e para seus repertórios de soluções, conceitos e papéis, formulados a partir de um tipo de conhecimento que emerge da experiência vivida. Rocha \& Eckert (2004:2) consideram que, "em maior ou menor grau, as narrativas orais faladas ou cantadas e os relatos míticos, ficcionais ou históricos" são "bons para pensar", pois são "formas diferenciadas das sociedades e culturas humanas de 'fabricarem' conhecimento sobre o mundo".

Jeanne Gagnebin (1987:9), no prefácio de "Magia e técnica, arte e política: ensaios sobre literatura e história da cultura", de Walter Benjamin, destaca a capacidade cognitiva e sentimental na transmissão da experiência comum, pois quando o "maravilhoso" é contado, ele capacita quem ouve a acessar dimensões e concepções locais. Já para Maluf (1999:70), uma das dimensões interpretativas sobre narrativa existentes na antropologia contemporânea consiste em tratar sobre o "fundo" de todas as histórias, buscando o sentido delas, indo além do literal. Seguimos tal abordagem, considerando a contextualização da produção da narrativa como um elemento de intepretação 
das concepções ambientais quilombolas, pois ela é parte da dinâmica da tradição oral, a qual depende, por sua vez, da conceitualização da cultura enquanto fator dinâmico que emerge da interação social com diferentes agentes e da recriação da tradição (Maluf 1999; Langdon 1999).

Destacamos que as narrativas são expressas em todos os lugares e, nas observações de campo, identificamos as "situações de enunciação" (Maluf 1999) que acontecem em espaços comunitários fora do domínio "formal" ("espaços de decisão" comunitários ${ }^{17}$ ); fora deles, as narrativas da "vida vivida" (Maluf 1999:74) emergem repletas de efeitos poéticos, que negam o formal e figuram os conhecimentos e as normas ecológicas quilombolas. Nas embarcações - um espaço de enunciação corriqueiro -, os indivíduos são levados a falar e a ouvir, a conversa flui e se narram as histórias de rio, de mata etc. Esses espaços compõem a "situação narrativa" de um contexto mais amplo dos "itinerários pessoais e coletivos de narração", experiências partilhadas de maneira coletiva que podem se tornar instrumentos de pesquisa (Maluf 1999:75). A narrativa, assim, tanto faz parte do discurso cotidiano humano quanto conta sobre os momentos especiais, simples e importantes, marcados por eventos em que um grupo se junta para se divertir e se comunicar (Langdon 1999).

A partir dessa metodologia e compreendendo que escutar faz parte do ofício do antropólogo ${ }^{18}$, exploramos os sentidos configurados e expressos na narrativa do personagem João Diriguidon, rememorando as espacialidades e temporalidades em que esse relato ocorre - importantes para a construção do texto etnográfico (Rocha \& Eckert 2004) -, bem como o processo de escuta e observação na embarcação como um contexto privilegiado de enunciação, registrado no caderno de campo - o qual também compreende notas tomadas em outras situações de observação e que compôs a presente contextualização.

Para chegar a alguns entendimentos e sentidos de preservação para essas comunidades, pela narrativa, construímos nossa interpretação depois de situado o contexto estudado, onde se configura o regime de conhecimento pelo qual se baseiam não só as práticas, mas as concepções e a memória coletiva quilombolas. Nesse universo, a narrativa ensinará, sobretudo, sobre a reciprocidade entre humanos e não humanos.

17 Lugares onde os quilombolas discutem pautas mais formais e legais - tais como a regularização fundiária, licenças ambientais e o próprio uso dos recursos ambientais das UC - com os órgãos institucionais.

18 Antes de qualquer coisa, compomos uma "comunidade de ouvintes" (Benjamin 1987:205). 


\section{4. "ELE NÃO MORREU, SE ENCANTOU...": NARRATIVA E RECIPROCIDADE NO TROMBETAS}

De acordo com os quilombolas, João Diriguidon figura entre um "personagem mítico" e um homem comum, que viveu entre eles como mais um pescador de tartarugas da região. Porém, foi um homem que, na linguagem local, "se encantou"19 por desconsiderar os "acordos ecológicos” (Mauss 2013) construídos entre as comunidades e os seres encantados (não humanos), os quais são necessários para a reprodução da vida material e simbólica, considerando que todo lugar tem "mãe" (Teixeira 2011) ou "dono" (Fausto 2008).

A história de João Diriguidon foi relatada enquanto uma das autoras transitava de uma ponta a outra no rio Trombetas e conversava com moradores de distintas comunidades. É uma história que, comumente, conta-se aos mais novos, os quais ajudaram, nessa ocasião, a complementar detalhes para o nosso melhor entendimento do caso de João Diriguidon ${ }^{20}$ :

\footnotetext{
$\mathrm{Na}$ "proa" de um barco, como normalmente se conhece a ponta de uma embarcação nos rios na Amazônia, um grupo de quilombolas, algumas mulheres, outros homens, adultos, jovens e crianças, subiam o rio Trombetas em direção às comunidades no alto curso... lá, nos esperavam para
}

mais uma reunião com a mineração, o ICMBio e, salvo engano, com o "pessoal do INCRA [Instituto Nacional de Colonização e Reforma Agrária]”, como eles costumam dizer. Estou pela segunda ou terceira vez fazendo esse trajeto em um pouco mais de dois anos que os conheço e visito em Oriximiná, mais especificamente o Alto Trombetas II. É verão e as crianças querem banhar no 'tabuleiro', as pontas de areia onde as tartarugas da Amazônia costumam, ou pelo menos costumavam, desovar. Os adultos não gostam muito da ideia, afinal sempre houve muita fiscalização, e as histórias sobre a observação dos técnicos ligadas a esses bichos sempre me pareceu 'pesada' demais em função dos muitos conflitos em torno da sua pesca/captura. O certo mesmo, como informação, é que os quilombolas daqui não acessam com facilidade essas praias, como antigamente faziam seus ancestrais nessas 'pontas de areia de desova'. Um dos presentes repreende o filho que chora na minha frente. $\mathrm{O}$ pai fala sobre um tal de João, que se encantou... Todos estão rindo, achando engraçado, sorrindo para mim, como se eu soubesse de quem estamos falando, mas na verdade eu não entendo a referência ou a piada. Uma das mulheres, que estava esfregando folhas de babosa numa de suas pernas me pergunta: “João Diriguidon?", e eu não sei o que responder. Apenas pergunto de volta: "do que estão falando?", e ela começa dizendo: "o João... ele tomava conta lá do tabuleiro... Aqueles últimos do rio. O tabuleiro ficava ali [subindo o rio]. Aí a casa dele ficava daquele lado [na margem esquerda] e saltava muita tartaruga e agora já não salta mais. Agora a gente já confere os cardumes que passa... naquele tempo, o João Diriguidon era um velhão que tomava conta das tartarugas, sabe? E nesse dia o mutum [uma ave que canta na beira do rio] começou a cantar, cantava que não era pra ele ir pra praia, que a mãe da tartaruga ia levar ele. $\mathrm{O}$ som que o

19 Sobre a incidência dos "encantados" em muitas partes da Amazônia e em outras regiões brasileiras, ver, por exemplo, Arruti (1996), Fausto (2008), Teixeira (2011) e Wawzyniak (2003).

20 A partir daqui, estão dispostas as sessões retiradas do caderno de campo que explicam a história. Dentro dos trechos, as narrações dos quilombolas foram destacadas entre aspas. 
mutum emite parece que dizia: 'João não vai pra praia que a tartaruga vai te levar'. Ele cantava: 'João, não vai pra praia'. O som é: 'hum hum hum... hum... hum... hum hum hum... hum... hum...hum...' [usando o corpo para se movimentar e cantar] porque o som do mutum é assim, e quando canta pra ti... [é porque tem algo errado]. Esse meu marido que sabe cantar bem isso [o canto do pássaro]. No entender da mãe do João, que ouvia o canto, a tartaruga ia levar ele... O mutum na árvore começava... [cantou novamente e apontava para o topo de uma árvore na várzea, área que costuma alagar de acordo com o ciclo das águas, durante o ano]. O mutum é ave que avisa do tabuleiro, lá é a casa dele. Lá onde João costumava aparecer, mas o rio é que é a casa dele, do João... Assim como temos nossa casa, com roça, trapiche..." (trecho do caderno de campo, 2017).

No Trombetas, o mutum (Mitu tuberosum) é a ave que "avisa sobre a chegada do verão": avisa sobre a aparição do lugar da desova da tartaruga, o "tabuleiro", no período em que as águas baixam e a praia aflora; e lembra aos moradores a história de João, avivando a memória e afetando os sentidos dos que ouvem seu canto e sabem o significado.

Em primeiro lugar, estamos diante de formas e sentidos de comunicação entre humanos e não humanos que lembra a relação dos Runa ${ }^{21}$ com seus cães (Kohn 2016). Segundo Kohn (2016), todo ser pressupõe um self(eu) diferente, que se localiza em um determinado ponto de vista e se engaja consigo mesmo e com os outros daquele grupo ou com selves externos. Os diferentes tipos de selves (humanos e não humanos) que se emaranham no convívio cotidiano abrem possibilidades múltiplas, em função dessa relação de interdependência e comunicação entre eles. Os modos Runa de conhecer os outros têm por base uma espécie de ecologia dos selves, pois todos os pontos de vista envolvidos naquele grupo ou organização social são capazes de estabelecer certa comunicação (Kohn 2016).

Assim como outros povos, os quilombolas desenvolveram comunicações e significações no Trombetas e se engajam com outros selves. Ao narrarem sobre João Diriguidon, os participantes daquela conversa da embarcação expressavam os tipos de comunicação que conhecem e compartilham com os outros seres, como ocorreu com a interpretação do aviso do mutum. A mensagem da ave se trata de uma comunicação baseada no entendimento que os humanos tecem sobre as expressões emitidas pelos animais, pois, mais do que ouvir o som, a mãe de João interpretou a intenção do aviso do mutum - de forma semelhante àquela como os Runa interpretam os sonhos dos cães (Kohn 2016).

Essa comunicação destaca-se na composição do quadro narrativo. Ao contar, a postura da narradora principal articulava a linguagem oral, corporal e musical para constituir cenas que estimulavam a imaginação dos ouvintes em uma 
paisagem para criar contextos narrativos, pois, segundo Maluf (1999), narrativas são formas de interpretação da experiência individual e coletiva, que, normalmente, são canalizadas via narrador: ao narrar a experiência humana, fala, sobretudo, do modo como partilha e constrói o sentido da narrativa, mesmo que este seja temporário, pois todo sentido pode ser modificado pela experiência individual e coletiva. Desse modo, impressionavam os elementos corporais para além da fala, ou seja, o uso de diversos canais de comunicação (Maluf 1999), desde a versão do canto do mutum até o olhar lançado aos filhos enquanto era enfatizado o comportamento de João.

Os quilombolas mais velhos são conhecidos como "mocambeiros", em referência àqueles que viveram o período de descenso, mas, sobretudo, porque são eles que narram os "causos" ou as histórias sobre a ocupação negra daquele lugar. Ao serem aqueles que ensinam, esses sujeitos se tornam "narradores”, figuras que expressam, estabelecem comunicação e, principalmente, aconselham os demais (Benjamin 1987). A figura do narrador efetua uma espécie de compartilhamento da experiência, pois possui um senso prático chamado pelo autor de sabedoria ou "o lado épico da verdade", o qual conforma a "arte de narrar", ou seja, a verbalização das vivências adquiridas no mundo da oralidade e do social, pois o narrador carrega a faculdade de intercambiar experiências diversas articuladas na memória (Benjamin 1987). Na medida em que é parte da experiência do vivido, os quilombolas narram, organizam e reafirmam as diversas normas ecológicas e sociais relativas aos modos de preservar aplicados à pesca e à caça, as quais podem ser entendidas a partir da história de João.

Os mocambeiros são narradores que acionam e elegem argumentos históricos e sensíveis da e para a memória do grupo para ensinar algo a quem ouve ou transmitir uma mensagem por meio da experiência contada (Benjamin 1987). No quilombo, as narrativas cumprem esse papel, na medida em que direcionam para uma aplicação prática do ensinamento - a preservação - em um cotidiano, onde a crença na presença de encantados informa sobre o modo de ser, estar e viver dessas populações, bem como demonstra a existência de uma cosmologia que engloba, além de acordos sociais de uso e consumo de recursos naturais, um modelo de entendimento em construção que repassa conhecimentos. Assim, os mais jovens aprendem sobre ecologia por meio da reciprocidade e do respeito entre os seres.

Ingold (2010:9) destaca que os processos de geração de conhecimento acontecem na vida dos seres humanos reais "menos por um suprimento acumulado de representações e mais por uma educação da atenção", na qual a aprendizagem 
sobre algo é realizada pela orientação falada. Pela oralidade também acontece o entendimento sobre uma "tarefagem" específica, ou seja, modo de ser, fazer e viver que orienta como uma rota contada e compreensível, podendo ser seguida pelo indivíduo em sua relação com o ambiente (Ingold 2010:21).

No processo de geração de conhecimento, é fundamental que haja uma interação "organismoambiente" funcionando como um desenvolvimento que gere elos entre narradores e iniciantes, pois as pessoas criam a si e aos seus ambientes no terreno das relações humanas por meio da geração de conhecimentos com base na vida vivida (Ingold 1995, 2010). No Trombetas, as narrativas orientam a aplicação desses saberes, pois, além de aprender os acordos morais, entende-se que o ambiente é composto por seres fora da esfera do humano, e que diversidade e abundância de recursos dependem, sobretudo, de aprender sobre o cuidado com a natureza circundante e as relações sociais que a envolvem (Latour 2005).

O contexto narrativo, então, é criado no ato de rememorar que o narrador produz um real situado. Halbwachs (2003:46) destaca a importância da reconstituição do ambiente para a lembrança porque os elementos que constituem a memória estão localizados e imbricados nesse lugar reconstituído, em que acontece a arte de narrar. No quadro montado no primeiro trecho, percebemos que o respeito ao ciclo da natureza, por meio do tabu da encantaria, explicita que há um valor de reciprocidade - nos termos de Mauss (2013) - existente em acordos coletivos, que consideram a presença de outros seres não propriamente humanos no contexto daquele território, oferecendo parâmetros de convivência da vida social.

$\mathrm{Na}$ Amazônia, os encantados podem manifestar-se de muitas formas: como bichos do fundo, presentes nos rios e igarapés; ou sob a forma de cobras, peixes, botos, jacarés e tartarugas (Maués 2005). Nessas condições, são, por vezes, considerados perigosos, pois podem punir os humanos, ao avaliarem suas posturas, modos de se portar no ambiente natural e modos de utilizá-lo. Aparecem, ainda, nos manguezais ou nas praias na forma humana ("oiaras"), como pessoas conhecidas, amigos ou parentes que levam as pessoas para o fundo (Maués 2005). Nesse caso, quem não corresponde à determinada postura ou não a respeita fica suscetível a punições do ponto de vista comunitário e da encantaria (Maués 2005).

Um outro sentido de encantaria aparece entre os indígenas Pankararu, do Nordeste brasileiro, os quais consideram os encantados como "conselheiros", personagens da vida simbólica e social que compõem um "corpo de entidades sobrenaturais" nos rituais da etnia, vivendo 
nas águas e podendo representar elementos de diferenciação étnica (Arruti 1996) 22 .

A narrativa de encantaria pode expressar, então, orientações, acordos e/ou tabus sociais com relação a "entidades morais" (Descola 1992), no caso dos encantados do Trombetas, mais especificamente a tartaruga maior do rio. São "entidades morais" porque não morrem propriamente, mas passam a existir enquanto "criaturas" outras que assumem "perspectiva" distinta da humana, podendo se manifestar como um animal. Assim, as narrativas parecem nos informar tanto sobre os acordos morais de convívio quanto sobre a gestão do equilíbrio socioambiental dos moradores locais e seu entorno (Mauss 2013). Por integrar a perspectiva de preservação dessa população relativa ao equilíbrio ambiental do lugar, a narrativa de João informa sobre um importante aspecto das relações entre humanos e não humanos: a convivência regida pela reciprocidade, um princípio por meio do qual o respeito só é concedido a quem sabe respeitar, ou seja, é um convívio atravessado por posturas de troca (Mauss 2013). Essa convivência é narrada, sobretudo, pelos mais velhos, expressando as dinâmicas temporalmente reconfiguradas e constantemente atualizadas pelas mudanças ocorridas no território.

O quadro narrativo, configurado enquanto transitávamos pelo rio entre territórios quilombolas, era composto de variadas versões da história que oscilaram em detalhes em outras oportunidades de encontro, mas mantinham seu sentido específico sobre a necessidade da preservação e sobre a preocupação com o equilíbrio ambiental. Ao final, busca-se reafirmar os ensinamentos que chamamos de "moral" e "socioambiental", fundados na observação aproximada e na interação, pois a cultura e o modo de vida quilombola, mais do que dominar e se apropriar dessa natureza, se orientam pelo convívio histórico e socialmente estabelecido de interdependência e respeito pelas "entidades morais" (Descola 1992), que compõem a paisagem do Trombetas. Assim, torna-se crucial a negociação entre os quilombolas no que diz respeito à interpretação final sobre a eventual quebra de algum tipo de regra ou código de conduta moral, a partir dos acordos sociais e ecológicos de convivência no local.

Essas relações compõem uma parte importante da memória coletiva das comunidades. Havendo uma relação de respeito sob uma perspectiva

22 Diferenciação em um contexto de disputa com outras etnias indígenas, ou se tornando o "caminho" que conduz os Pankararu aos direitos e ao reconhecimento do governo, por exemplo. Guardar o "segredo" dos encantados nesse grupo social significa guardar a forma como se "fabricam" esses seres, pois eles "não são deuses nem espíritos de ancestrais mortos, são índios que descobriram o segredo de se encantar e que, assim, alcançaram a imortalidade”, formando uma comunidade que pode ser ampliada no tempo. O segredo em torno dessas entidades concerne à proteção do elemento contrastivo que garante a ligação dessa etnia com o "sobrenatural" e os diferencia dos demais grupos avizinhados (Arruti 1996:95, grifo nosso). 
ecológica da preservação entre os quilombolas e os não humanos, a relação de reciprocidade comunicada por narrativas se funda na memória coletiva, dispositivo que alimenta e reproduz uma educação da atenção aos mais jovens. Por meio da memória coletiva, os quilombolas configuram seus entendimentos em interação com perspectivas outras, como as dos técnicos do ICMBio. Podemos afirmar que a memória do grupo é coletiva e atravessada pela pública - aquela que pode advir de agentes externos ao grupo - porque não há uma separação radical e excludente de entendimentos entre quilombolas e ICMBio. Pelo contrário, interagindo, são capazes de compor amplamente a narrativa atual sobre a "tartaruga da Amazônia" no alto Trombetas. Sendo assim, como seres sociais, "nunca estamos sós e cada memória individual é um ponto de vista sobre a memória coletiva, que muda segundo o lugar que ali ocupo e esse mesmo lugar muda segundo as relações que mantenho com outros ambientes" (Halbwachs 2003:60). No momento da narração, todos os presentes contribuíram lembrando juntos, acrescentando detalhes, corrigindo passagens sobre um personagem ou mesmo mudando as entonações pertinentes, como no canto do mutum, o que destaca a importância desse elemento e a representação da ave como figura conhecedora e guardiã da área do tabuleiro.
Desse modo, “para que a nossa memória se aproveite da memória dos outros, não basta que estes nos apresentem seus testemunhos: também é preciso que ela não tenha deixado de concordar com as memórias deles e que existam muitos pontos de contato" que nos faça recordar para formular uma base comum (Halbwachs 2003:39). Ou seja, o primeiro testemunho ao qual podemos recorrer será sempre o nosso, e não basta concordância com outros: o mais importante é que haja a troca, a reiteração e a revisão dos fatos retratados coletivamente (Halbwachs 2003). Entre os quilombolas, isso se dá também em função da dinâmica socioambiental vivida por eles, pois as transformações e os efeitos da presença da mineração e dos órgãos de fiscalização ambiental no território passaram a integrar os elementos acionados na composição da memória coletiva.

A memória coletiva quilombola, então, pode ser entendida como uma categoria histórica e étnica, por deter um significado de resistência e de autoafirmação do grupo diante e para o poder estatal (Acevedo \& Castro 1988; Arruti 2006), de modo que consegue dinamizar elementos para disputar entre si e com os agentes externos. Ademais, essa categoria é marcadora da diferença entre a classificação e a delimitação territorial quilombola e as fronteiras administrativas impostas pelos órgãos ambientais, como o ICMBio. Assim 
se formula o quadro de resistência, presente na narrativa, na ideia de que o território é, sobretudo, lugar de conquista onde os quilombolas aprenderam a morar, a conviver com e a classificar/hierarquizar a natureza envolvente com a qual se sentem vinculados. É na interdependência, no respeito e na reciprocidade com os seres, o ambiente e os coletivos humanos que se forma a memória coletiva dos quilombolas e a (re)produção de seus conhecimentos. Esse vínculo existe na medida em que suas reminiscências preservam antigos e novos caminhos de rio, trilhas de caças, "paragens" de pesca e outros elementos que assiduamente povoam a memória e possibilitam interpretar suas vivências, entendimentos e atividades, bem como orientam e conservam lugares de encantes que compõem as paisagens.

Nessas inter-relações, destaca-se um aspecto importante: toda classificação supera o caos e é realizada segundo lógicas, concepções e experiências próprias de cada grupo social (LéviStrauss 1970). Os quilombolas, ao classificarem o ambiente onde vivem em espaços domésticos e espaços de encantes, por exemplo, associam fortemente esse último ao rio que, segundo contam, é "lugar de morada" de outros seres a quem devem respeito e deferência. $\mathrm{O}$ rio, no imaginário quilombola, é um dos lugares mais respeitados pelos comunitários. Lévi-Strauss (1970:27) afirmou que "cada coisa sagrada deve estar em seu lugar" e que isso "a torna sagrada, pois, se fosse suprimida, mesmo em pensamento, toda a ordem do universo seria destruída”, pois é necessário resguardar a esse sagrado "o lugar que lhe cabe". Não à toa, os encantados amazônicos são associados à terra, à flora e à água, suas moradas e símbolos materiais e naturais de lugares que situam sua presença (Maués 2005; Silva 2014).

Essa ordenação quilombola do seu universo territorial para sua sobrevivência, de acordo com a espacialidade que cada self ocupa, demarca fronteiras - desde as mais maleáveis entre humanos e animais, até as mais rígidas, mas não intransponíveis, entre humanos e encantados -, que, de certo modo, restringem os lugares ocupados e informam o tabu da transposição a certos espaços, fatores indispensáveis para o equilíbrio da convivência. Ou seja, os encantados são parte da produção da vida social e cosmológica da região dos rios Trombetas e Erepecuru que se articulam com outros seres, compondo organização social (Teixeira 2011). No caso da narrativa, há posições não dicotômicas e alternância entre um "sujeito" que incide sobre um "objeto" na estrutura social (Viveiros de Castro 2002): os encantados possuem o poder de determinação dos limites entre os espaços e aplicam sanções em um campo perceptivo em que os quilombolas produzem os conceitos locais. 
São ordenações que, segundo Fausto (2008), se dão em uma relação de domínio/maestria entre humanos e não humanos caracterizando uma posição que engloba não a propriedade privada da natureza, mas um sentido que, na sociabilidade amazônica, significa exercer interferência sobre esse mundo: os "donos" dos lugares ou das coisas exercem ações de controle e/ou proteção dos seres e das coisas em torno de determinado grupo/ espaço social. No Trombetas, a tartaruga-mãe é um dos seres encantados que exerce a ação de proteção e controle sobre, por exemplo, o que pode ou não ser pescado do ambiente em questão: quando as tartarugas fogem para longe do convívio humano, o encantado aciona o "castigo" para renegociar a reciprocidade com e entre quilombolas. Mais do que explicar o significado da categoria em si, é importante atentar "para a relação que ela implica" (Fausto 2008:332): ilustrar a crença comum nos encantados, na relação ecológica de cuidado e proteção da "natureza", pois nela vivem poderosas entidades capazes de agir sobre os humanos que não observam algum acordo coletivo - firmado na tradição da oralidade local, por meio das representações simbólicas - sobre os usos dos recursos naturais.

Esses acordos comunitários de uso e consumo dos recursos disponíveis no entorno ajudam na sobrevivência satisfatória de quem vive no território
(Fidelis \& Carvalho 2015; Maués 2005; Silva 2014; Wawzyniak 2008). No baixo Amazonas, quando são quebrados, há casos em que nenhum tipo de "tratamento" resolve o problema das pessoas que ofenderam os "bichos" e foram "afetadas". Assim, a comunidade relata prezar por uma conduta ecológica que corresponde aos acordos, sobretudo para não enfrentar os "estágios comuns" do processo de encantamento (Silva 2014) por castigo, por "sequestro" ou para receber uma dádiva (Mauss 2013). Quando acontece, o transgressor acaba se "engerando" 23 em animal: a pessoa afetada ou "assombrada" pela "flechada de bicho" passa a habitar novos corpos, perspectivas e lugares considerados fora da ordem do humano (Wawzyniak 2003, 2008).

Assim, ao partir de uma história que abarca os referenciais comunitários, o narrador aconselha e causa reflexão (Benjamin 1987:203) em prol da reciprocidade e empreende a "educação da atenção" (Ingold 2010). Esse intercâmbio de experiências pela oralidade acontece a partir da memória coletiva, fundada na construção social - modificada e acionada de diferentes formas quando é necessário (Halbwachs 2003), como na narrativa em questão. Ou seja, no universo da caça e da pesca na região, comportamentos como o de João rompem o ciclo de reciprocidade entre as partes, e um caçador ou

23 Para mais informações sobre a categoria, ver Wawzyniak (2003). 
pescador desrespeitoso está sujeito aos efeitos desse descumprimento. O "castigo" acontece individualmente quando alguém pode se "engerar" diante do "dono" protetor; ou, de maneira coletiva, direta ou indiretamente (Maués 2005), como na estiagem do recurso natural, por conta da pesca indevida. Todos esses elementos se movem para moldar a concepção quilombola de preservação.

\section{SOBRE JOÃO DIRIGUIDON: NARRAR, CONHECER E PRESERVAR}

A matriarca de uma das famílias mais antigas, conhecidas e respeitadas do alto rio Trombetas nos explicou que João Diriguidon foi um homem que se encantou ao tentar pescar mais tartarugas do que ele necessitava. Por isso, ele passou a habitar o lago do Abuí, tido como o lugar de morada das tartarugas, e não retornou à comunidade.

A viagem saindo do alto Trombetas II ao alto Trombetas I leva de três a quatro horas, dependendo do tipo de embarcação utilizada. Enfrentávamos a subida do rio quando a matriarca, se embalando numa rede, me contou mais sobre João Diriguidon. Ele foi um rapaz como qualquer outro, que aprendeu a andar nesse rio e a pescar tartaruga. Ele morava próximo a um antigo tabuleiro onde a desova acontecia, às margens do Trombetas. João era jovem e ajudava sua mãe na pescaria do 'bicho de casco', pois morava na praia em que os animais viviam, mas "depois de velho, virou ganancioso". Certo dia, "o mutum começou a cantar que não era pra ele ir pra praia que a mãe da tartaruga ia levar ele... Mãe é coisa séria, a mãe já viveu muito, e João não respeitou a mãe do rio e a sua própria mãe. Se não respeita a própria mãe, não respeita mãe de nenhum lugar”. Ela dizia que João era muito ganancioso porque pegava as tartarugas "fora do normal" e, como bem assinalou, "todos os lugares têm suas mães, todo lago, todo rio, a própria mãe dele o advertiu: 'não vai à praia pescar tartarugas'”, por mais que a praia estivesse cheia delas. "Ele era ganancioso e ambicioso, nada mais o satisfazia. Ele podia ter todas as tartarugas, mas ele queria mais... Ele disse: 'Ahhh, mamãe! Eu vou pra praia". Enquanto a narradora insistia em destacar a ganância de João, olhava para os filhos, como quem ensina algo mais que a história. "Ele pegava tartaruga fora do normal, só que todos os lugares têm suas mães, todo lago, todo rio...", dizia novamente enquanto olhava para as águas escuras do rio Trombetas. Continuando, ela contou sobre a mãe do igarapé, a mãe do rio, para dizer que João não se importou com nada disso, nem com sua mãe que dizia "meu filho, não vai", e ele foi. Enquanto ela contava as características da praia do Tabuleiro, era possível imaginá-la, na medida em que nos aproximávamos dela. Quando João chegou a essa praia e viu muita tartaruga "de toda marca", grande e pequena, foi que "ele avistou a grandona e o olho dele foi certo". Ele viu a tartaruga, e ia andando a acompanhando, quando finalmente ele a tocou com uma mão. Essa mão prendeu em seu casco e grudou; na tentativa de se soltar, ele puxou com outra mão e ela também grudou. Ele foi empurrar com o pé e grudou também, ele ficou ajoelhado, agachado. A tartaruga o levou, mergulhou no rio, foi nadando com ele preso. Quando a tartaruga passou na frente da casa da mãe de João, a mãe o viu indo embora e chorou muitas noites no tabuleiro. "Dizem que a tartaruga fez morada no lago do Abuí, e dizem que muitos anos atrás o João boiou lá”, submergiu. Dizem que ele "tá diferente, com os cabelos compridos, sem voz... Ele não morreu, se encantou" (trecho do caderno de campo, 2017). 
O lago Abuí é um lugar de encante que povoa o imaginário da região. Consideram-no uma espécie de refúgio, quase um santuário, um ponto de equilíbrio ecológico para as espécies:

\begin{abstract}
"O João, coitado, está cabeludo, aparece vez em quando", as pessoas dizem. "Onde ele mora tem muito encantado, mas também tem muita tartaruga, tem muita fartura de pirarucu e tambaqui [peixes de grande porte]". É "Longínuo" [lago dos "ginos"]. "Nesse lago ninguém chega, mas é o mais rico. Fica pra banda do Abuí... do Lago, ninguém vai lá. Ela [tartarugamãe] levou ele e lá eles moram. Esse meu sogro sonhou que ganhava uma fortuna, que era pra ele ir lá pra esse lago que ele encontraria. No sonho, a voz orientou que ele fosse com mais duas pessoas, que iriam ficar rico. Mas ele preferiu não ir, a mulher dele não deixou ele ir. Esse lago é rico. Quando as pessoas dizem que está sumindo tartaruga é pra lá que elas estão indo... Sumindo pra cá, pra lá vivendo. $\mathrm{O}$ problema é chegar no Abuí e não achar o caminho [de volta]. Ninguém acha" (trecho do caderno de campo, 2017).
\end{abstract}

O lago do Abuí tornou-se, então, uma referência de abundância para onde as tartarugas se encaminham. Segundo os quilombolas, diferente dos quelônios, que são privados do convívio e não possuem a destreza das tartarugas, essas necessitam do entorno equilibrado para se reproduzir, crescer saudáveis e acessar o lago do Abuí.

Os encantados, como vimos, são retratados como pessoas comuns que passaram por um processo de morte corporal para habitar um mundo do encante, normalmente um lugar subaquático ou escondido nas matas, situado entre o plano espiritual e o tempo natural (Silva 2014). Há uma ambiguidade nessa figura: ela pode "fazer o bem ou o mal", dependendo da postura da pessoa encantada, e o encantamento pode ou não culminar em um "engeramento" (Wawzyniak 2008) propriamente dito. João teve sua perspectiva humana afetada, mas não passou pelo "engeramento" total; o que houve foi a sua junção ao corpo encantado de uma tartaruga. $\mathrm{Na}$ narrativa, então, enfatiza-se, para os mais jovens, a deferência às entidades encantadas porque são as mães dos lugares e das coisas e estipulam as normas para o convívio (Teixeira 2011). Por isso, a narrativa sobre João é importante, na medida em que o lugar de seu "encantamento" é parte do corpo físico do animal diante do qual uma determinada postura social de convívio fora desrespeitada.

Nesse contexto, é comum ouvir dos quilombolas que a tartaruga entrou em um período de escassez severa desde meados da década de 1980, contraditoriamente, um ano depois de instaladas as bases de fiscalização do órgão ambiental no rio Trombetas. Vanzolini (1967) afirma que, de maneira geral, quando as tartarugas estão dispostas na natureza, desenvolvem "estímulos sensoriais" que lhes permitem realizar atividades importantes para sua reprodução, como voltar aos seus pontos de nascimento para futuras desovas. Essa tese corrobora a concepção local de que a tartaruga 
precisa estar livre na natureza para adquirir sua sociabilidade ecológica, que lhe fortalece e proporciona seu pleno domínio sobre as águas.

Entretanto, com os planos de manejo que não permitem a entrada dos quilombolas na REBIO, acontece a fiscalização e a punição do ICMBio nos barcos dos comunitários, em função do que o órgão chama de captura "ilegal" da tartaruga ou de qualquer espécie apanhada nas influências da REBIO. Isso interferiu diretamente na relação dos quilombolas com as tartarugas, uma vez que, segundo explicaram, elas são tidas como criaturas de rio; contam que elas "saltavam e agora já não salta mais, a gente já confere os cardumes que passa”. A narrativa sobre o homem que se encantou pela tartaruga, então, passou a informar a resposta à inobservância do ciclo de reciprocidade e do respeito ao espaço de reprodução da tartaruga.

Se cada self (Kohn 2016) ocupa um lugar no mundo existindo de maneira interdependente, ao romper acordos morais e ecológicos estabelecidos entre os seus e os protetores do lugar, João abalou o imprescindível princípio de reciprocidade, fazendo com que a mãe do lugar atuasse e transformasse o transgressor em um símbolo dos efeitos sociais do não respeito aos acordos morais/ecológicos.

"Se ocorre uma coisa dessas, os peixes que mais se pesca se afastam e vão para onde está devastado de gente. Eles buscam mais alimentação, eles vão se afastando. Isso não quer dizer que acaba. Isso é uma coisa que o homem não vai conseguir destruir que é a natureza. Quanto mais ele desmata aqui, em outro lugar aumenta mais de fartura, mas fica longe da gente. Por isso tem que conviver, seja por bem ou mal. [...]. Olha a tartaruga, um tempo atrás você ia numa praia você ficava doido de tanta tartaruga, hoje em dia não tem aquela quantidade que tinha antes, só que elas não foram embora, elas só se afastaram porque conhecem o rio. Aquelas que não conhecem [o ambiente] ficam [...]. Se me perguntarem o que eu acho do Ibama [ICMBio], eu acho que melhorou com o Ibama. Quando eu me entendi eu já vi esse povo aí [os técnicos]. A minha mãe, o meu pai, os meus avós ainda viram fartura de tartaruga porque é um dos nossos alimentos, um dos pratos que hoje em dia é muito difícil comer, comprar, vender, trocar. A tartaruga e o ovo eu ainda vi. Essa fartura de ovo. Eu não tenho nada contra o Ibama, eu acho que é até bom porque no tempo que estamos hoje se não tivesse o Ibama pra defender as tartarugas talvez não existissem nem mais quelônios. Todo mundo quer vender. É mais fácil de levar para a cidade os quelônios. Tartaruga tá desaparecendo mesmo" (trecho do caderno de campo, 2017).

Nessas relações ecológicas, a estreita relação das comunidades com os "bichos de casco" resulta em formas variadas de identificação e caracterização deles (Nascimento et al. 2012). Destacamos que, considerando as necessidades alimentícias das comunidades, esses animais silvestres foram e continuam sendo adquiridos por meio de caça e pesca - ainda importantes -, pois a tartaruga é uma das principais fontes de proteína para as comunidades tradicionais da Amazônia (Fachín-Terán \& Vogt 2004; Ferreira 
Júnior 2009). Entretanto, são relações com a natureza que ultrapassam a discussão sobre o mero consumo de carne (Barroso \& Moura 2016), pois são um meio que possibilita pensar a produção de conhecimentos locais (LéviStrauss 1970) de maneira que as classificações humanas fornecem pistas sobre a constituição de "saberes populares" (Barroso \& Moura 2016) ou de "conhecimentos tradicionais" (Cunha 2009) indispensáveis para o reconhecimento dessas populações e para o debate no campo das ciências (Barroso \& Moura 2016).

O termo "quelônio", introduzido no cotidiano local pela REBIO, foi usado pelos quilombolas para redefinir as suas classificações de características das tartarugas em uma espécie de "invenção" para comparar e diferenciar os modelos dados. A "ciência do concreto" - a sensibilidade tátil, visual e degustativa - compõe parte significativa dos modos de conhecimentos que concebem o mundo por meio do cheiro, do sabor, do tato, formando, finalmente, um conjunto de elementos que transpassam interpretações e possibilitam classificações (LéviStrauss 1970), por um lado, do "bicho de casco" mais presente no cotidiano e no imaginário local e também do objeto de estudos e monitoramento do ICMBio:

"Eu vi no Ibama um tanque grande, enorme, com muita tartaruga grande, tracajá [outro bicho de casco] pequeno, até tartaruguinha pequena que eles pegam e levam embora das praias para o tanque. Agora também muitos desses queloniozinhos que eles soltam na praia. Ano passado nós fomos para um evento em que eles soltavam os quelônios criados nos tanques, no rio. Quantas ali vão sobreviver? Muito pouco. Primeiro, quando eles soltam, um urubu mesmo, ou um jacaré, um gavião, ficam esperando ali. Jacaré pega mesmo. Quando elas se criavam por conta, era melhor pra elas sobreviverem, elas sobreviviam. Outra coisa, tartaruga de viveiro, os quelônios, os alimentos que eles comem não são elas mesmas que conseguiram, não viveram para conseguir. Eles que dão. O bebê precisa do leite da mãe, é a sua natureza! A tartaruga precisa também, pra ser tartaruga ela precisa ser da natureza. Os alimentos não são os mesmos alimentos [...], a gente compra tartaruga por aí, eu falo mesmo. A gente pega uns quelônios que eu calculo que é essas tartarugas que eles solta no viveiro, elas são muito magras. Não dá pra comer gostoso, não tem gordura boa pra tratar da saúde... Não tem prazer de pescar com liberdade. Se pesca, é criminoso. A gente gosta de tartaruga, tartaruga grande, sadia, com banha. Os quelônios acabam morrendo. Até ela pegar o ritmo da natureza, ela acaba morrendo porque tá fraca. $\mathrm{O}$ Ibama conserva. Mas esse projeto não funciona. A gente não come quelônio deles, a gente não usa quelônio, que eles fiquem tranquilos porque não é a mesma coisa. Tá sumindo do rio, tá sumindo ovo, tartaruga..." (trecho do caderno de campo, 2017).

Os quilombolas identificam uma tartaruga por meio da observação do casco (normalmente mais escuro e espesso); nele, identificam o que entendem ser as "marcas de sua trajetória no território", e chegam a especular a sua idade e a espessura de sua gordura ("banha"). Nessa relação de conhecimento e convivência, a tartaruga não é apenas o sinônimo 
de uma iguaria proteica apreciada historicamente, mas ela igualmente integra um quadro de matériaprima fundamental, pois sua gordura é considerada eficaz e tradicionalmente utilizada em tratamentos de acometimentos físicos. Segundo os quilombolas, para que a banha de uma tartaruga seja eficaz, ela precisa atender a uma estética "bonita", ou seja, que acaba por informar sobre o seu estado, se é saudável ou não, se cresceu no "convívio natural equilibrado", regido pelos acordos ecológicos, pois a tartaruga é vista como um ser relacional não alheia à presença humana e, por isso, verdadeiramente livre no seu habitat natural.

Podemos inferir que estar "equilibrado e livre na natureza" parece ser a condição de um crescimento que a permita adquirir caraterísticas fisiológicas necessárias ao "gosto", "espessura", "cor" e "textura" próprios da visão local de uma tartaruga adulta altamente proteica. Esse self, então, deve estar engajado com outros e com elementos do entorno para aprender a sobreviver nesse ambiente, na concepção local, mais “saudável”:

A tartaruga na praia pode passar 50 , 100 anos. "A primeira desova dela é na praia que ela nasceu, porque lá é o caminho que a mãe dela ensinou pra ela [...]. Dizem que ela demora 30, 40 anos pra desovar e eu acho isso difícil, eu não sei se é verdade. Uma tartaruga demora muito pra crescer. Uma vez eu me lembro que eu peguei uma pequena assim pra eu criar e depois soltei porque tava enjoado que todo dia eu olhava e nada dela crescer. Passei uns quatro anos com ela, ela não crescia nada. Dentro de um tanque é difícil porque eu não tenho a ração que os biólogos dão, por isso que eu digo que ela demora muito pra crescer; presa, fica igual quelônio" (trecho do caderno de campo, 2017).

Narrativas como a de João Diriguidon ensinam e informam sobre interesses quilombolas presentes na ordenação de velhos e novos elementos que integram sua realidade social. Pela maneira singular de articular memória coletiva, "educação para atenção" (Ingold 2010) da natureza e oralidade, a que destacamos forneceu um contexto de produção e de significação de conceitos nativos (Viveiros de Castro 2002) em interação com categorias exógenas. Com ela, compreendemos a concepção de preservação entre os quilombolas da região sob uma dupla dimensão: a memorial - que orienta a atenção realizada pelas gerações antigas para com as atuais - por meio de uma gramática cosmológico-ecológica diante da qual se "costura" a outra dimensão; a sociopolítica que, ao contrastar e interagir com a conservação, atualiza tradição, memória, oralidade, conceitos nativos e comportamentos sociopolíticos, para mobilizar a dinâmica local de classificação frente ao poder de atuação do ICMBio.

O contraste da segunda dimensão pode funcionar mais como ferramenta de aproximação, apropriação e invenção para a classificação do que de diferenciação para exclusão. Nos relatos, identificamos uma 
dinâmica de entendimento local que reconhece a importância da conservação pelo aparato estatal de proteção ambiental na região, mas, ao mesmo tempo, demonstra que existem estratégias locais de aproximação e teste para uma reclassificação e organização de mundo que deveriam ser consideradas diante das "regras de Estado".

A fricção de concepções corresponde à dupla face da diferença existente no processo de cismogênese (Bateson 2008), pois a narrativa também informa a classificação das categorias quelônio/tartaruga organizadas no mundo social e político das "entidades governamentais" que atuam no território, por meio de metodologias de conservação que afastam os bichos de casco dos humanos, impossibilitando uma espécie de interação ecológica por eles vista como necessária. Percebemos, então, que as "entidades governamentais" também criam seus acordos de convivência e um deles é a proibição da pesca/captura dos quelônios.

Diante disso, apreendemos das narrativas as estratégias da memória que, ao ser transmitida e rememorada, expõe pistas interessantes sobre o cosmo local, que interage com o institucional. Em alguma medida, tartarugas e quelônios também apresentam sinais sobre as estratégias para o reconhecimento das comunidades quilombolas e, para tal, movimentam classificações, categorias e concepções, ou mesmo a diferença perante outros grupos étnicos do Trombetas e outras entidades, como o órgão ambiental. O "caminho da tartaruga" (Arruti 1996:27) ajudou-nos a "observar como, onde e para que fins a diferença é agenciada”, pois, nesse contexto, "as experiências mais ou menos privadas" puderam se tornar "motivos morais de uma luta pelo reconhecimento" (Montero et al. 2011:34).

Chega-se, então, a várias classificações, além da diferença fisiológica, na classificação local sobre a espécie e o entendimento que comunica o que é tartaruga ou quelônio. No mundo dos acordos morais com os encantados, a reciprocidade orienta as ações de maneira majoritária e, dessa forma, um "equilíbrio ecológico" é negociado entre humanos e não humanos. O quelônio inaugura outra dimensão nessa relação, igualmente importante, cuja postura ecológica não permite interação e dificulta a reprodução social quilombola e o estabelecimento de qualquer reciprocidade. Portanto, a classificação opõe as duas categorias, mas pode potencialmente aproximá-las e organizá-las; para nós, a aproximação pode ser entendida como estratégia de conexão entre dois domínios da vida quilombola: o cosmológico, no ordenamento de mundo, e o estatal, diante do qual figuram como comunidades tradicionais, mas também como "presenças que desequilibram", não ecológicas aos olhos da ideia de conservação do órgão ambiental, pois os agentes externos, muitas vezes, resumem a relação dos quilombolas com os bichos de casco à pesca predatória e à necessidade alimentar. 


\section{CONSIDERAÇÕES FINAIS}

Como demonstramos, a criação e a gestão de UC em áreas de ocupação tradicional e regulada por uma metodologia própria, baseada na "gestão de conflitos" (Zhouri et al. 2007), infere diretamente na criação de políticas de conservação adotadas por órgãos ambientais estatais, como é o caso da REBIO do Rio Trombetas e da FLONA de SaracáTaquera. Apresentando o Trombetas, procuramos refletir sobre os sentidos relacionais de preservação para a população quilombola que vive na região, e adentramos outras discussões importantes, como os conflitos em torno dos recursos naturais na área, diante dos quais pudemos esboçar entendimentos sobre as relações entre o modo de vida, o conhecimento local e as transformações advindas com a chegada de agentes externos, como o ICMBio.

As dimensões e concepções presentes na narrativa de João se tratam, sobretudo, de posturas ecológicas e morais estabelecidas e transmitidas pela oralidade, pois a história assinala que, em uma convivência de reciprocidade entre quilombolas e tartarugas, não há lugar para comportamentos "gananciosos" ou de "cobiça", o que levou João Diriguidon para a morada da tartaruga. A partir da memória coletiva e da narrativa oral de João, vimos que existe uma postura moral repassada por meio dos narradores às gerações mais novas. Esse ensinamento os orienta dentro de uma "educação da atenção" (Ingold 2010) para observar e prezar pelos acordos ecológicos e de reciprocidade firmados com os encantados que compõem a paisagem do lugar. Essa orientação oferece indícios sobre o modo quilombola de praticar a preservação: ela acontece em consonância a uma dinâmica de troca e deferência para com os "donos dos lugares", os quais asseguram que determinados recursos não faltem aos quilombolas, na medida em que esses prezem pelo equilíbrio, respeitando e convivendo harmoniosamente para poder utilizar os recursos ambientais importantes para sua subsistência.

Em contrapartida, com a política conservatória do ICMBio, essa dinâmica se viu alterada. Essa mudança pode ser observada na atualização da memória coletiva e na classificação quilombola que diferencia tartarugas e quelônios, pois, diante da presença do ICMBio e de sua metodologia de conservação, novas classificações e entendimentos estão em curso como produtos da interação, apropriação e redefinição de mundos.

Ao destacar o seu modo de ordenar o mundo e os seus princípios de convivência, os quilombolas demarcam seu conhecimento sobre seu território, bem como entendem como a natureza pode responder reciprocamente de forma mais ou menos equilibrada às preocupações e ações em prol da manutenção de recursos ambientais. De modo mais amplo, os conhecimentos quilombolas 
demonstram que sua classificação é estratégia política de reconhecimento, pois o mecanismo de preservação quilombola é pautado na socialização geracional que ensina, na conversa com os jovens, sobre as consequências da quebra de um princípio moral entre humanos e não humanos, algo que prescinde um convívio equilibrado.

Diante da narrativa de reciprocidade, memória coletiva e interação com o ICMBio, destacamos que há não apenas uma distinção entre tartarugas e quelônios, mas uma diferenciação entre preservação e conservação que pode aproximar, ao invés de separar, no caminho de pensar um problema de interesse comum, mas que é tratado de maneira distinta pelos agentes envolvidos. Assim, a pesca/ captura dos bichos de casco ganha outro sentido entre os quilombolas, quando muitos dizem que "quilombola não gosta de quelônio e quelônio não gosta de quilombola": na medida em que o termo técnico foi adaptado à realidade mítica, a narrativa, entre outras funções mencionadas, avança para reforçar a interação da diferença entre as concepções nativas e exógenas quanto às tartarugas.

Assim, situamos uma disputa de sentidos diferentes com semelhante preocupação ecológica, a de proteção da tartaruga-da-amazônia. O processo de disputa nos apresentou uma série de classificações que, quando tomadas como objeto de interpretação, demonstraram que a intenção de proteção é compartilhada por quilombolas e ICMBio, apesar de advirem de perspectivas distintas. A diferença entre essas classificações informa que as ontologias dos mundos são potencialmente comensuráveis, apesar do conflito que, nesse contexto, é construtivo, pois gera algo novo.

A conservação do ICMBio, na concepção dos quilombolas, trouxe para o Trombetas acordos que não geram reciprocidade e dificultam a reprodução do modo de ser, fazer e viver das comunidades. Estabelecer a distinção entre os animais, então, significa dizer que só é possível uma ação ecológica conjunta se houver princípios de troca. Isso pode acontecer se houver reconhecimento do ICMBio de que a postura local de preservação não necessita excluir humanos da convivência com as tartarugas, pois os quilombolas não desejam ser vistos como criminosos ou predadores da natureza por terem nesse animal uma fonte de alimento, medicamento e ferramenta de memória e conhecimento.

Uma vez reconhecido o entendimento quilombola de preservação, também se reconhece sua memória, conhecimentos e modos de ser e estar no território e entorno. Interpretando a narrativa, observamos que, por mais que a política de conservação objetive a proteção integral da espécie, existe um conhecimento local que muito tem a dizer e a trocar, o qual apresenta e situa sua eficácia, por meio de narrativas que contam sobre coletivos de interação que compõem o lugar (Latour 2005). Assim, para preservar, é necessário 
que haja socialização entre humanos e animais, isso pode ser rompido e possibilitar o encontro orientada pela atenção dos quilombolas para a de um "chão comum" (Almeida 2003), mesmo necessidade da reciprocidade com as entidades que temporário e mutável, para dialogar. Assim, morais presentes em seu mundo.

Mesmo que de forma assimétrica, as "quase verdades” (Almeida 2003) disputadas entre comunidades e órgão coexistem, e sua aparente incomensurabilidade os tornaria incapazes de preservação e conservação são mundos que podem estabelecer uma ponte comunicativa e repensar a presença humana na relação com a natureza e a intervenção na maneira como os quilombolas vivem seu território, o que, à sua maneira e de acordo negociar e estabelecer consensos. Entretanto, com sua tradição, lutam para manter e reconhecer.

\section{REFERÊNCIAS}

Acevedo, R., e E. M. Castro. 1998. Negros do Trombetas: guardiões de matas e rios. Belém: Cejup/ UFPA-NAEA.

Almeida, M. 2003. Relativismo antropológico e objetividade etnográfica. Campos - Revista de Antropologia 3:9-29. DOI: http://dx.doi.org/10.5380/cam.v3i0.1585

Arruti, J. M. P. A. 1996. O reencantamento do mundo: trama histórica e arranjos territoriais Pankararu. Dissertação de Mestrado, Museu Nacional, Universidade Federal do Rio de Janeiro, Departamento de Antropologia Social, Rio de Janeiro.

Arruti, J. M. P. A. 2006. Mocambo: antropologia e história do processo de formação quilombola. Florianópolis: EDUSC.

Arruti, J. M. P. A. 2013. Dossiê: políticas de reconhecimento e sobreposições territoriais. RURIS: Revista do Centro de Estudos Rurais - UNICAMP 7(2):7-12.

Barroso, W. A., e N. A. de Moura. 2016. Etnoconhecimento morfológico e ecológico de quelônios (Podocnemis expansa e P. unifilis) em uma comunidade ribeirinha. Biota Amazônia 6(1):91-95. DOI: http://dx.doi.org/10.18561/2179-5746/biotaamazonia.v6n1p91-95 
Bateson, G. 2008. Naven: um exame dos problemas sugeridos por um retrato compósito da cultura de uma tribo da Nova Guiné, desenhado a partir a partir de três perspectivas. São Paulo: EdUSP.

Benjamin, W. 1987. Magia e técnica, arte e política: ensaios sobre literatura e história da cultura. Obras Escolhidas de Walter Benjamin, v. 1. São Paulo: Editora Brasiliense.

Brasil. 2004. Plano de Manejo da Reserva Biológica do Rio Trombetas. Brasília: Edições Ibama.

Carvalho, L. G. 2013. Relações de trabalho nos balatais do Pará. Horizontes Antropológicos 19(39):373400. DOI: https://doi.org/10.1590/S0104-71832013000100015

Corrêa, H. B. 1978. Contribuição ao estudo dos quelônios amazônicos registrando casos de albinismo observados em Podocnemis expansa e Podocnemis sextuberculata. Boletim Técnico IBDF 5:3-26.

Cunha, M. C. 2009. Relações entre conhecimentos tradicionais e conhecimentos científicos, in Cultura com aspas e outros ensaios. São Paulo: Cosac Naify.

Descola, P. 1992. Societies of nature and the nature of society, in Conceptualizing society. Editado por A. Kuper, pp. 107-126. London/New York: Routledge.

Ernst, C. H., e R. W. Barbour. 1989. Turtles of the World. Washington: Smithsonian Institution Press.

Evans-Pritchard, E. E. 1978. Interesse pelo gado, in Os Nuer, pp. 25-59. São Paulo: Perspectiva.

Fachín-Terán, A., e R. C. Vogt. 2004. Estrutura populacional, tamanho e razão sexual de Podocnemis unifilis (Testudines, Podocnemididae) no Rio Guaporé (RO), norte do Brasil. Phyllomedusa 3(1): 29-42. DOI: https://doi.org/10.11606/issn.2316-9079.v3i1p29-42 
Fausto, C. 2008. Donos demais: maestria e domínio na Amazônia. Mana 14(2):329-366. DOI: https:// doi.org/10.1590/S0104-93132008000200003

Ferreira Júnior, P. D. 2009. Aspectos ecológicos da determinação sexual em tartarugas. Acta Amazonica 39(1):139-154.

Fidelis, J. C., e L. G. Carvalho. 2015. Noções de corpo saúde e doença: uma análise no Tapajós. Anais da V Reunião Equatorial de Antropologia, XIV Reuniões de Antropólogos Norte e Nordeste. Disponível em: http://www.evento.ufal.br/anaisreaabanne/gts_download/_Juliana\%20Cardoso\%20Fidelis\%20-\%20 1020589\%20-\%203923\%20-\%20corrigido.pdf. Acesso em: 2 jul. 2020.

Fidelis, J. C. 2019. “Tratamento diferenciado”: sobre reconhecimento e consideração em torno do sistema biomédico no Alto Trombetas. Dissertação de Mestrado, Universidade Federal do Pará, Departamento de Sociologia e Antropologia, Belém.

Francisco, L. R. 1997. Répteis do Brasil: manutenção em cativeiro. São José dos Pinhais: Amaro.

Gagnebin, J. M. (1987). Prefácio, in Magia e técnica, arte e política: ensaios sobre literatura e história da cultura. Editado por Walter Benjamin, pp. 7-20. Obras Escolhidas de Walter Benjamin, v. 1. São Paulo: Editora Brasiliense.

Geertz, C. 2008. Um jogo absorvente: notas sobre a briga de galo balinesa, in A interpretação das culturas, pp. 185-213. Rio de Janeiro: LTC.

Halbwachs, M. 2003. A memória coletiva. São Paulo: Vértice.

Howard, C. V. 2002. A domesticação das mercadorias: estratégias Waiwai, in Pacificando o branco: cosmologias do contato no norte amazônico. Organizado por B. Albert e A. Ramos, pp. 25-60. São Paulo: UNESP. 
Ingold, T. 1995. Building, dwelling, living: how animals and people make themselves at home in the world, in Shifting contexts: transformations in anthropological knowledge. Editado por M. Strathern, pp. 57-80. London: Routledge.

Ingold, T. 2010. Da transmissão de representações à educação da atenção. Educação 33(1):6-25.

Instituto de Desenvolvimento Florestal e da Biodiversidade do Estado do Pará (Ideflor-bio). 2016. Ideflorbio avança no processo de criação do Mosaico da Calha Norte. Disponível em: https://ideflorbio.pa.gov. br/2016/08/ideflor-bio-avanca-no-processo-de-criacao-do-mosaico-da-calha-norte/. Acesso em: 6 jul. 2020.

Instituto do Homem e Meio Ambiente da Amazônia (Imazon). 2013. Calha Norte sustentável: situação atual e perspectivas - Parte 1. Disponível em: https://imazon.org.br/calha-norte-sustentavel-situacaoatual-e-perspectivas-parte-1-2/. Acesso em: 6 jul. 2020.

Kohn, E. 2016. Como os cães sonham: naturezas amazônicas e as políticas do engajamento transespécie. Ponto Urbe 19:1-36. DOI: https://doi.org/10.4000/pontourbe.3326

Langdon, E. J. 1999. A fixação da narrativa: do mito para a poética de literatura oral. Horizontes Antropológicos 5(12):13-36. DOI: https://doi.org/10.1590/S0104-71831999000300002

Latour, B. 2005. Reagregando o social: uma introdução à teoria do ator-rede. Salvador: EDUFBA.

Lévi-Strauss, C. 1970. A ciência do concreto, in O pensamento selvagem, pp. 15-50. Campinas: Papirus.

Maluf, S. W. 1999. Antropologia, narrativas e a busca de sentido. Horizontes Antropológicos 5(12):69-82. DOI: https://doi.org/10.1590/S0104-71831999000300005

Maués, R. H. 2005. Um aspecto da diversidade cultural do caboclo amazônico: a religião. Estudos Avançados 19(53):259-274. DOI: https://doi.org/10.1590/S0103-40142005000100016 
Mauss, M. 2013. Ensaio sobre a dádiva: forma e razão da troca nas sociedades arcaicas. São Paulo: Cosac Naify.

Montero, P., J. M. Arruti, e C. Pompa. 2011. Para uma antropologia do político, in O horizonte da política: questões emergentes e agenda de pesquisa. Organizado por A. G. Lavalle, pp. 145-184. São Paulo: UNESP.

Nascimento, P. S., M. C. Carvalho e S. Farias. Os quelônios de Roraima. Biologia Geral e Experimental $12(1): 1-48$.

O’Dwyer, E. C. 2002. Os quilombos do Trombetas e do Erepecuru-Cuminá, in Quilombos: identidade étnica e territorialidade. Organizado por E. C. O’Dwyer, pp. 255-280. Rio de Janeiro: Editora FGV.

O’Dwyer, E. C. 2008. Profetismos e práticas de cura: saber tradicional dos remanescentes de quilombo de Oriximiná-PA. CEPPAC: Centro de Pesquisa e Pós-Graduação sobre as Américas/UNB 5:2-13.

Rocha, A. L. C., e C. Eckert. 2004. A narrativa e a captura do movimento da vida vivida. Iluminuras 5(9):1-19. DOI: https://doi.org/10.22456/1984-1191.9184

Salles, V. 2005. O negro no Pará sob o regime da escravidão. Belém: Instituto de Artes do Pará.

Santos, E. N., e L. G. Carvalho. 2015. Memórias do comércio da juta no baixo-amazonas. Anais da V Reunião Equatorial de Antropologia, XIV Reuniões de Antropólogos Norte e Nordeste. Disponível em: http://www.evento.ufal.br/anaisreaabanne/gts_download/_Elber\%20Norton\%20 de\%20Souza\%20Dos\%20Santos\%20-\%201020634\%20-\%203941\%20-\%20corrigido.pdf. Acesso em: 2 jul. 2020.

Scaramuzzi, I. A. B. 2016. Extrativismo e as relações com a natureza em comunidades quilombolas do rio Trombetas/Oriximiná/Pará. Tese de Doutorado, Instituto de Filosofia e Ciências Humanas, Universidade Estadual de Campinas, Departamento de Antropologia Social, Campinas. 
Silva, G. S. 2014. Encantados da Amazônia: os espíritos da natureza. Anais do XVI Encontro Regional de História da ANPUH-Rio: Saberes e Práticas Científicas. Disponível em: http://www.encontro2014. rj.anpuh.org/resources/anais/28/1400206941_ARQUIVO_ArtigoparaaANPUH,EncantadosdaAmazonia. pdf. Acesso em: 5 jul. 2020.

Teixeira, R. D. 2011. Todo lugar tem uma mãe: sobre os filhos de Erepecuru. Revista Anthropológicas 17(2):117-146.

Vanzolini, P. E. 1967. Notes on the nesting behavior of Podocnemis expansa in the Amazon valley (Testudines, Pelomedusidae). Papéis Avulsos de Zoologia 20:191-215.

Viveiros de Castro, E. 2002. O nativo relativo. Mana 8(1):113-148. DOI: https://doi.org/10.1590/S010493132002000100005

Wanderley, L. J. M. 2005. Tem “cerca” para negro na Amazônia! A luta dos quilombolas do Trombetas - PA por titulação e uso da terra. Simpósio Nacional de Geografia Agrária. Anais do III Simpósio Internacional de Geografia Agrária, II fornada Ariovaldo Umbelino de Oliveira.

Wanderley, L. J. M. 2008. Conflitos e movimentos sociais populares em área de mineração na Amazônia brasileira. Rio de Janeiro: UFRJ/PPGG.

Wawzyniak, J. V. 2003. Engerar”: uma categoria cosmológica sobre pessoa, saúde e corpo. Ilha: Revista de Antropologia 5(2):33-55.

Wawzyniak, J. V. 2008. Assombro de olhada de bicho: uma etnografia das concepções e ações em saúde entre ribeirinhos do baixo rio Tapajós, Pará-Brasil. Tese de Doutorado, Universidade Federal de São Carlos, Departamento de Ciências Humanas, São Carlos.

Wawzyniak, J. V. 2012. Humanos e não-humanos no universo transformacional dos ribeirinhos do rio Tapajós-Pará. Mediações 17(1):17-32. DOI: http://dx.doi.org/10.5433/2176-6665.2012v17n1p17 
Zhouri, A., K. Laschefski, e D. B. Pereira. 2007. A insustentável leveza da política ambiental: desenvolvimento e conflitos socioambientais. São Paulo: Autêntica Editora.

Zhouri, A. 2008. Justiça ambiental, diversidade cultural e accountability: desafios para a governança ambiental. Revista Brasileira de Ciências Sociais 23(68):97-107. DOI: https://doi.org/10.1590/S010269092008000300007 